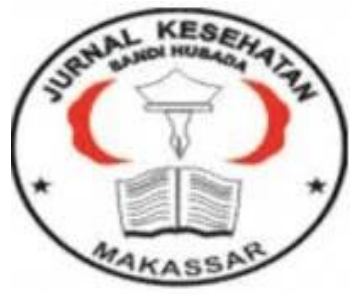

Jurnal Ilmiah Kesehatan Sandi Husada

hhttps://akper-sandikarsa.e-journal.id/JIKSH

Vol 10, No, 2, Desember 2019, pp;331-335

p-ISSN: 2354-6093 dan e-ISSN: 2654-4563

DOI: $10.35816 /$ jiskh.v10i2.182

\title{
Patient Empowerment Dan Self-Management Pada Pasien Diabetes Mellitus Tipe 2
}

Patient Empowerment and Self-Management in Type 2 Diabetes Mellitus Patients

Muhammad Abiyoso Ramadhan

Pendidikan Dokter, Fakultas Kedokteran, Universitas Lampung

\section{Artikel info}

Received; 24 Desember 2019

Revised; 26 Desember 2019

Accepted; 30 Desember 2019

\section{Artikel history:}

\section{Abstract}

Diabetes mellitus is a metabolic disease were hyperglycemia happens. This is caused by abnormality of insulin production or the distribution. Diabetes mellitus prevalention has increased till now all over the world including in Indonesia. Depends on Basic Health Research (RISKESDAS), prevalention of diabetes mellitus at 2018 increased 2, 6\% compared to 2013 and reach 14 millions of life. Diabetes mellitus is not only health problems, it also about behaviour and lifestyle. Diabetes mellitus could happens due to unhealthy behaviour and lifesytle. Therefore diabetes mellitus patient be required some approach were able to change patient behaviour and lifestyle. Patient empowerment and self-management is an approach that could change patient behaviour and lifestyle.

\begin{abstract}
Abstrak.
Diabetes melitus adalah penyakit metabolisme dimana terjadi hiperglikemia. Hal ini disebabkan oleh abnormalitas pada produksi insulin atau pada pendistribusiannya. Prevalensi diabetes melitus hingga saat ini terus meningkat di seluruh dunia termasuk di Indonesia. Menurut hasil Riset kesehatan Dasar (Riskesdas), diperoleh bahwa prevalensi diabetes melitus pada Riskesdas 2018 meningkat 2,6\% dibandingkan tahun 2013 dan mencapai angka 14 juta jiwa. Diabetes melitus bukanlah hanya masalah kesehatan, namun juga masalah perilaku dan gaya hidup. Diabetes melitus dapat terjadi karena perilaku dan gaya hidup yang tidak sehat. Maka dari itu dibutuhkan pendekatan yang dapat mengubah perilaku dan gaya hidup pasien diabetes melitus. Patient empowerment dan self-management merupakan proses pendekatan yang dapat memperbaiki perilaku dan gaya hidup pasien.
\end{abstract}

\footnotetext{
Keywords:

Patient empowerment;

Self-Managemen;

Diabetes Mellitus;
}

Coresponden author: Email:mabiyoso@gmail.com

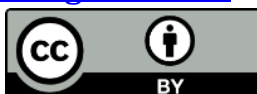

artikel dengan akses terbuka dibawah lisensi CC BY -4.0 


\section{Pendahuluan}

Diabetes Melitus merupakan suatu kelompok penyakit metabolik dengan karakteristik hiperglikemia yang terjadi karena kelainan sekresi insulin, kinerja insulin atau kedua-duanya (Riddle et al., 2018). Menurut hasil Riset kesehatan Dasar (Riskesdas), diperoleh bahwa prevalensi diabetes mellitus(DM) pada Riskesdas 2018 meningkat 2,6\% dibandingkan tahun 2013. Riskesdas 2018 memperkirakan jumlah penderita DM pada usia diatas 15 tahun adalah sebanyak 8,5\% penduduk Indonesia, atau sekitar 14 juta jiwa (Kementrian Kesehatan RI, 2018).

Patient empowerment atau pemberdayaan pasien adalah proses yang dirancang untuk mengubah sikap seseorang dimana jika digunakan pada pasien DM dapat memperbaiki perkembangan penyakit pasien (Anderson and Funnell, 2010; Chiauzzi et al., 2016). Dalam konteks penyakit tidak menular, self management dapat diartikan sebagai rangkaian proses yang dilakukan oleh pasien untuk menjaga kondisi penyakitnya. Pada diabetes mellitus tipe 2 , self-management sangat penting untuk mengurangi biaya pengobatan dan meningkatkan pemberdayaan pasien, serta meningkatkan partisipasi pasien dalam rencana pengobatan tanpa menurunkan kualitas hidup (Isaksson et al., 2014; Collins and Rochfort, 2016).

\section{Metode}

Penelitian ini merupakan studi literature review, di mana peneliti mencari, menggabungkan inti sari serta menganalisis fakta dari beberapa sumber ilmiah yang akurat dan valid. Studi literatur menyajikan ulang materi yang diterbitkan sebelumnya, dan melaporkan fakta atau analisis baru. Tinjauan literatur memberikan ringkasan berupa publikasi terbaik dan paling relevan.

\section{Hasil Dan Pembahasan}

Diabetes Melitus (DM) didefinisikan sebagai suatu penyakit atau gangguan metabolisme kronis dengan multi etiologi yang ditandai dengan tingginya kadar gula darah disertai dengan gangguan metabolisme karbohidrat, lipid dan protein sebagai akibat dari insufisiensi fungsi insulin. Insufisiensi insulin dapat disebabkan oleh gangguan produksi insulin oleh sel-sel beta Langerhans kelenjar pankreas atau disebabkan oleh kurang responsifnya sel-sel tubuh terhadap insulin (Depkes RI, 2009). Menurut WHO, Diabetes Melitus (DM) didefinisikan sebagai suatu penyakit atau gangguan metabolisme kronis dengan multi etiologi yang ditandai dengan tingginya kadar gula darah disertai dengan gangguan metabolisme karbohidrat, lipid dan protein sebagai akibat dari insufisiensi fungsi insulin. Insufisiensi insulin dapat disebabkan oleh gangguan produksi insulin oleh sel-sel beta Langerhans kelenjar pankreas atau disebabkan oleh kurang responsifnya sel-sel tubuh terhadap insulin. Dalam penatalaksanaan DM, praktisi kesehatan menerapkan 4 pilar penatalaksanaan DM yang berupa edukasi, terapi gizi medis, latihan jasmani, dan intervensi farmakologis. Dengan penatalaksanaan yang memperhatikan berbagai aspek tersebut diharapkan dapat meningkatkan kualitas hidup pasien DM (WHO, 2010).

Pemberdayaan dapat didefinisikan sebagai proses multi-dimensi yang bertujuan untuk membantu orang untuk mencapai kontrol kehidupan diri dan meningkatkan kapasitas terhadap permasalahan diri (PERKENI, 2015). Patient empowerment adalah proses dari perubahan kebiasaan yang lebih berfokus pada pengetahuan dan kontrol diri pasien terhadap tubuhnya, penyakit, dan pengobatan. Dapat dikatakan empowerment adalah proses mengaktifkan pasien, dengan harapan dapat mengurangi kebiasaan dan asumsi pasif dari pasien. Suatu kegiatan dapat dikatakan patient empowerment apabila dapat memberdayakan pasien untuk meningkatkan efikasi dirinya. Contoh kegiatan yang mengandung konsep patient empowerment adalah edukasi pasien, selfempowerment, dukungan keluarga dan lingkungan berupa motivasi, penetapan kebijakan yang mendukung, dsb (European Patient Forum and European Patients' Forum, 2015). 


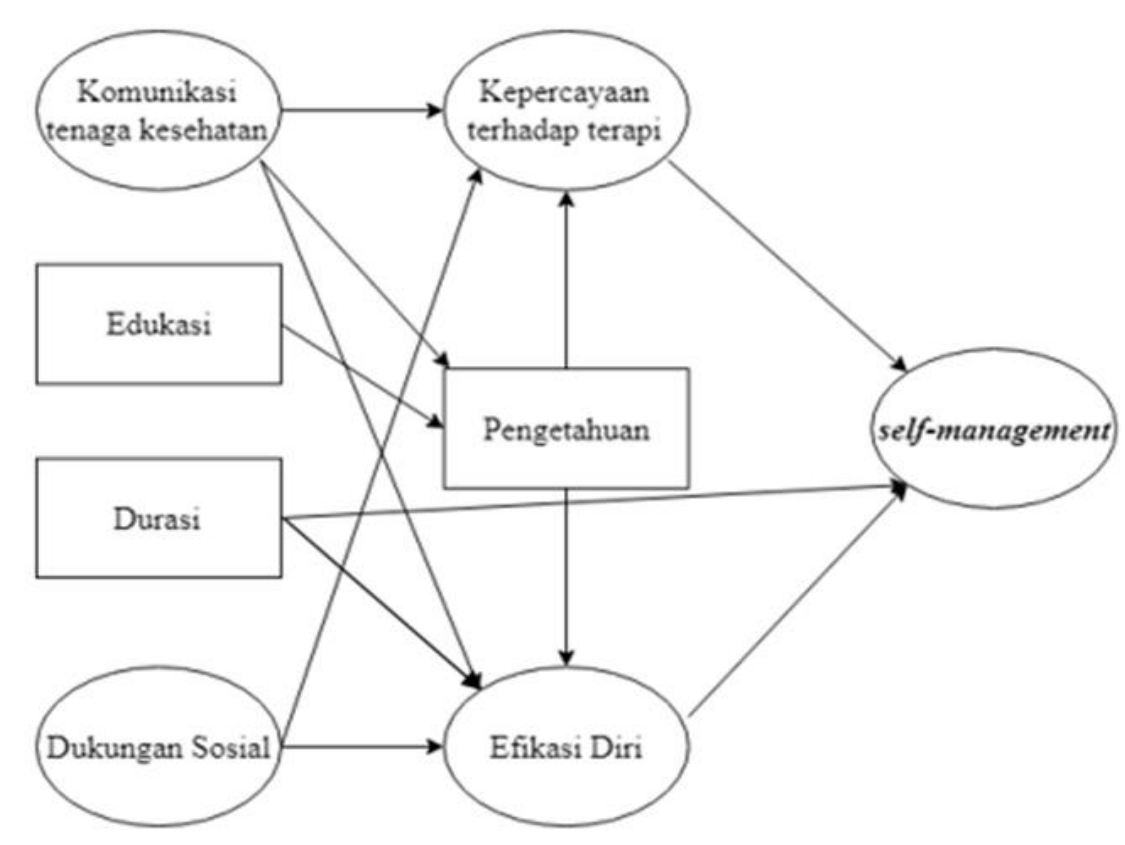

Gambar 1. Faktor-faktor yang mempengaruhi self-management (Udlis, 2011)

Terdapat beberapa faktor yang berperan terhadap patient empowerment. Menurut Czuba, empowerment merupakan multi-dimensi yang meliputi dimensi sosiologi, psikologi, ekonomi, dan dimensi lainnya . Menurut analisis yang dilakukan oleh Aojulat et al, terdapat dua dimensi yang berperan dalam proses patient empowerment : dimensi inter-personal dan dimensi intra-personal. Oleh karena itu, patient empowerment dapat dilihat dari sudut pandang pasien, penyedia layanan kesehatan, ataupun keduanya. Saat dilihat dari sudut pandang penyedia layanan kesehatan, empowerment diartikan sebagai sebuah proses edukasi dan komunikasi dimana pengetahuan dan nilai-nilai diberikan. Dilihat dari sudut pandang pasien, empowerment diartikan sebagai proses perubahan diri (Chatzimarkakis, 2010). Menurut Bravo et al, terdapat tiga subjek yang berperan terhadap patient empowerment yaitu pasien, penyedia layanan kesehatan, dan sistem layahan kesehatan (Bravo et al., 2015). Penyedia layanan kesehatan berfokus pada patient-centered intervention, konseling, pelatihan, dsb. Sistem layanan kesehatan berfokus memberikan intervensi melalui self-management disease programme, expert patient programme chronic, personalized care planning, dan patient education (Ku and Kegels, 2015).

Konsep self-management pada penyakit kronis merupakan suatu proses dimana pasien terlibat dalam strategi multi-dimensi untuk mengidentifikasi kebutuhan dirinya. Menurut pakar lain, saat ini self-management dikenali sebagai komponen essensial dalam pengobatan penyakit kronis (Bravo et al., 2015). Kemampuan self-management berkaitan dengan efikasi diri, dimana dapat didukung dengan pendekatan patient empowerment (Isaksson et al., 2014). Self-management mengacu pada kemampuan individual untuk mengontrol gejala, pengobatan, dampak fisik dan psikososial, serta perubahan gaya hidup terhadap penyakit kronis dan disabilitas (Howell, Harth and Brown, 2017). Target dari penerapan self-management adalah kadar gula darah yang terkontrol dan menurunkan resiko komplikasi dalam jangka panjang (Udlis, 2011).

Berdasarkan penelitian yang dilakukan oleh Xu Yin dkk, didapatkan beberapa faktor yang mempengaruhi Diabetes Self-Management (DSM). Faktor-faktor tersebut dibagi menjadi dua kriteria, yaitu faktor langsung dan faktor tidak langsung. Faktor langsung meliputi kepercayaan 
terhadap terapi, durasi penyakit, dan efikasi diri. Faktor tidak langsung meliputi komunikasi tenaga kesehatan, edukasi, dukungan social, dan pengetahuan. Dari berbagai faktor tersebut terdapat faktor yang berkaitan satu sama lain. Komunikasi tenaga kesehatan berpengaruh terhadap kepercayaan terhadap terapi, pengetahuan dan efikasi diri. Edukasi mempengaruhi tingkat pengetahuan pasien dimana berdampak pada tingkat kepercayaan diri dan efikasi diri pasien. Lalu lama durasi selain menjadi faktor langsung DSM juga berpengaruh terhadap efikasi diri pasien. Dukungan sosial tidak lepas dari mempengaruhi kepercayaan terhadap terapi dan efikasi diri pasien (Udlis, 2011).

Terdapat sebuah penelitian meta-analisis mengenai efektivitas self-management pada pasien diabetes mellitus tipe 2. Penelitian tersebut dilakukan dengan cara mengumpulkan serta mengidentifikasi 21 penelitian randomized controlled trials serupa. Hasil dari penelitian ini membuktikan bahwa penerapan self-management pada pasien diabetes melitus tipe 2 efektif untuk meningkatkan perkembangan dalam aspek klinis, gaya hidup, dan psikososial (Ahola and Groop, 2012).

\section{Simpulan Dan Saran}

Diabetes melitus merupakan penyakit metabolik dimana kadar gula dalam darah tinggi yang disebabkan oleh abnormalitas insulin. Penyakit ini tidak dapat disembuhkan dan akan menetap seumur hidup, namun dapat diberikan terapi agar mengurangi gejala dan mencegah komplikasi. Apabila tidak mendapatkan tatalaksana dengan baik, diabetes melitus dapat menurunkan kualitas hidup pasiennya. Sebagai upaya untuk meningkatkan performa pengobatan pasien diabetes melitus, pendekatan patient empowerment dan self-management dapat diterapkan. Patient empowerment merupakan suatu pendekatan multi-dimensi dimana bertujuan untuk meningkatkan efikasi diri pasien. Self-management merupakan proses dimana pasien memiliki efikasi diri untuk mengontrol penyakit yang dialaminya.

\section{Daftar Rujukan}

Ahola, A. J. and Groop, P. (2012) 'Review Article Barriers to self-management of diabetes', pp. 413420.

Anderson, R. M. and Funnell, M. M. (2010) 'Patient empowerment: Myths and misconceptions', Patient Education and Counseling. Elsevier Ireland Ltd, 79(3), pp. 277-282. Available at: http://dx.doi.org/10.1016/i.pec.2009.07.025.

Bravo, P. et al. (2015) 'Conceptualising patient empowerment: A mixed methods study', BMC Health Services Research. BMC Health Services Research, 15(1), pp. 1-14. Available at: http://dx.doi.org/10.1186/s12913-015-0907-z.

Chatzimarkakis, J. (2010) 'Why patients should be more empowered: A European perspective on lessons learned in the management of diabetes', Journal of Diabetes Science and Technology, 4(6), pp. 1570-1573.

Chiauzzi, E. et al. (2016) 'Factors in Patient Empowerment: A Survey of an Online Patient Research Network', Patient. Springer International Publishing, 9(6), pp. 511-523.

Collins, C. and Rochfort, A. (2016) 'Promoting Self-Management and Patient Empowerment in Primary Care'.

Depkes RI (2009) 'Masalah Terapi Obat', Pharmaceutical care untuk penyakit diabetes mellitus,p.55.

European Patient Forum and European Patients' Forum (2015) 'EPF Background Brief: Patient Empowerment', A Strong Patient's Voice to Drive Better Health in Europe, p. 12. Available at:http://www.eu-patient.eu/globalassets/campaign-patient empowerment/briefing paperpatient-empowerment final external.pdf\%0Awww.eu patient.eu. 
Howell, D., Harth, T. and Brown, J. (2017) 'Self-management education interventions for patients with cancer: a systematic review'. Supportive Care in Cancer, pp. 1323-1355. doi:10.1007/s00520-016-3500-z.

Isaksson, U. et al. (2014) 'Diabetes empowerment and needs for self-management support among people with type 2 diabetes in a rural inland community in northern Sweden', Caring Sciences.

Kementrian Kesehatan RI (2018) RISKESDAS 2018.

Ku, G. M. V and Kegels, G. (2015) 'Implementing elements of a context-adapted chronic care model to improve fi rst-line diabetes care : effects on assessment of chronic illness care and glycaemic control among people with diabetes enrolled to the First-Line Diabetes Care ( FiLDCare ) Project in the Northern Philippines', (November 2014), pp. 1-11. doi:10.1017/S1463423614000553.

PERKENI (2006) 'Konsensus Pengelolaan dan Pencegahan Diabetes Melitus Tipe 2 di Indonesia', (Diabetes Melitus).

Riddle, M. C. et al. (2018) 'Standard medical care in diabetes 2018', Diabetes Care, 41(1). Udlis, K. A. (2011) 'Self-management in chronic illness : concept and dimensional analysis', Nursing and Healthcare of Chronic Illness, pp. 130-139.

WHO (2010) 'Definition and diagnosis of diabetes mellitus and intermediate hyperglycemia'. 